\title{
约 \\ O CONTROLE DE CONSTITUCIONALIDADE NA ITÁLIA
}

JUDICIAL REVIEW IN ITALY

EL CONTROL DE CONSTITUCIONALIDAD EN ITALIA

\author{
Eduardo Meira Zauli ${ }^{1}$ \\ Guilherme Sales Meira Zauli
}

\begin{abstract}
Resumo: Este artigo aborda o tema do controle de constitucionalidade italiano. Procede-se a uma caracterização institucional da Corte Constitucional italiana instituída pela Constituição de 1948; são tratadas as modalidades incidental e concentrada do controle de constitucionalidade na Itália e apontadas as tendências evolutivas do sistema italiano no sentido de uma conjugação de elementos institucionais provenientes dos modelos americano e europeu kelseniano de controle de constitucionalidade.
\end{abstract}

Palavras-chave: Controle de constitucionalidade; Itália; Corte Constitucional.

Abstract: This article addresses the issue of Italian judicial review. An institutional characterization of the Italian Constitutional Court instituted by the Constitution of 1948 is carried out; the incidental and concentrated modalities of judicial review in Italy are dealt with and the evolutionary tendencies of the Italian system are pointed out in the sense of a combination of institutional elements from the American and European Kelsenian models of constitutionality control.

Keywords: Judicial Review; Italy; Constitutional Court.

Resumen: Este artículo aborda la cuestión del control de constitucionalidad italiano. Se lleva a cabo una caracterización institucional del Tribunal Constitucional italiano instituida por la Constitución de 1948; se abordan las modalidades incidentales y concentradas de control de constitucionalidad en Italia y se señalan las tendencias evolutivas del sistema italiano en el sentido de una combinación de elementos institucionales de los modelos de control de constitucionalidad americano y europeo kelseniano.

Palabras clave: Control de Constitucionalidad; Italia; Corte Constitucional.

\section{A CORTE CONSTITUCIONAL}

Órgão de garantia constitucional previsto na Constituição Italiana de 1948 e instalada em 1956 com a prerrogativa de concentrar o exercício do controle de constitucionalidade na República Italiana, a Corte Costituzionale é o órgão encarregado de decidir as controvérsias acerca da legitimidade constitucional das leis e dos atos com força de lei do Estado e das Regiões; sobre os conflitos de atribuição entre os poderes do Estado e sobre aqueles entre o Estado e as

\footnotetext{
${ }^{1}$ Prof. Departamento Ciência Política da UFMG.Pós-Doutor em Ciência Política pela Universtà di Bologna. E-mail: emzauli@gmail.com

${ }^{2}$ Bacharel em Direito e Especialista em Direito Tributário pela PUCMG.E-mail: guilhermezauli@zauliadvocacia.com
} 
Regiões, e entre as Regiões.

Artigo 134 - O Tribunal Constitucional julga:

as controvérsias relativas à legitimidade constitucional de leis e atos com força de lei, do Estado e das Regiões; os conflitos de atribuições entre os poderes do Estado e entre o Estado e as Regiões e entre as Regiões; as acusações contra o Presidente da República, de acordo com a Constituição. (ITALIA, COSTITUZIONE, 1948, tradução dos autores).

Segundo Gianfranco Pasquino, a Corte Constitucional

Desempenha, portanto, ao mesmo tempo, o papel de árbitro entre os poderes do Estado, de juiz que decide sobre as leis e de garantidor da democracia com relação aos crimes cometidos por ministros e pelo presidente da República. (PASQUINO, 2011, p. 110, tradução dos autores).

Instalada em Roma, a Corte está sediada no Palazzo della Consulta, vizinho ao Palazzo del Quirinale (residência oficial do Chefe de Estado). Até mesmo sua localização geográfica e sua vizinhança têm sido lembradas como indicativos da posição ocupada pela Corte Constitucional no sistema político italiano:

Uma escolha feliz, esta da sede, não só porque o edifício do século XVIII é uma obra arquitetônica de grande beleza, mas também porque a sua localização expressa bem, simbolicamente, a posição da Corte constitucional: na colina "mais alta" de Roma, face a face com o Palazzo del Quirinale, sede do Presidente da República, a mais alta instituição representativa e, por sua vez, principalmente - como a Corte - com funções de garantia; relativamente longe, no entanto, dos palácios da Roma "política" (Montecitorio e Palazzo Madama, sedes das duas Câmaras, Palazzo Chigi, sede da Presidência do Conselho de Ministros, que é o topo do Governo, os vários ministérios) e da Roma "Judicial" (por exemplo, o "Palazzaccio", sede do Tribunal de Cassação, ou seja, a cúpula da magistratura). (CORTE COSTITUZIONALE, 2016, p. 16, tradução dos autores).

É composta por 15 juízes que cumprem um mandato de 9 anos: 5 eleitos pelo Parlamento; 5 escolhidos pelo Chefe de Estado; e 5 elegidos pela suprema magistratura ordinária e administrativa, sendo que destes últimos, 3 são provenientes da Corte Suprema di cassazione (Corte Suprema de Cassação), 1 do Consiglio di Stato (Conselho de Estado) e 1 da Corte dei conti (Corte de Contas), conforme depreende-se do artigo 135 da Constituição da República italiana conjugado com a Lei 11 de março de 1953, n. 87, e a Lei Constitucional 22 de novembro de 1967, n. 2.

Introduzida no ordenamento constitucional do Estado italiano na transição da ditadura fascista para a democracia ao final da $2^{\mathrm{a}}$ Guerra Mundial, a Corte Constitucional não encontra paralelo em nenhuma instituição italiana anterior à Constituição de 1948.

Antes da entrada em vigor da Constituição de 1948 vigorava na Itália o Estatuto do Reino, denominado Estatuto Fundamental da Monarquia de Savoia, de 04 de março de 1848, conhecido como Estatuto Albertino (Statuto Albertino) - por ter sido promulgado por Carlo Alberto di Savoia, Rei da Sardenha. O Estatuto Albertino definia uma forma de governo consubstanciada 
em uma monarquia constitucional, sendo caracterizado por ter sido uma Constituição flexível, passível de modificações através de leis ordinárias. Além disso, o Estatuto Albertino não previa um controle de legitimidade constitucional de leis e atos normativos, de maneira que um tribunal não podia recusar-se a aplicar uma lei por considera-la inconstitucional, o que seria interpretado como uma violação do princípio da separação dos poderes.

Segundo Carlo Guarnieri,

Tradicionalmente a Itália, como de resto os países da Europa continental, não conhecia um controle judicial de constitucionalidade. De fato, de acordo com o Estatuto Albertino, a Constituição em vigor em nosso país antes de 1948, um tribunal não poderia se recusar a aplicar uma lei porque que tenha sido considerada inconstitucional, em contraste com a Constituição, nem declará-la como tal e portanto cancelá-la do âmbito das normas jurídicas. Uma tentativa desse tipo teria sido interpretada como uma violação grave do princípio da separação dos poderes. (GUARNIERI, 2011, p. 28, tradução dos autores).

É importante considerar, em qualquer tentativa de compreender as razões que levaram a criação da Corte Constitucional na Itália, certas características do Poder Judiciário italiano à época da introdução do controle concentrado de constitucionalidade. Segundo Carlo Guarnieri, diferentemente do que ocorre nos países de common law, os tribunais italianos não eram - e não são - obrigados a respeitar os precedentes jurisprudenciais e então, pelo menos em teoria, poderiam verificar-se diferenças de orientações entre a Corte de Cassação - órgão de cúpula do Poder Judiciário italiano- e os tribunais inferiores; diferenças que poderiam ter consequências fortemente negativas. Além disso, os tribunais italianos não possuíam nem mesmo a autoridade moral e o prestígio dos tribunais de common law, em particular da magistratura federal americana. Além disso, uma vez que os juízes da época foram educados, recrutados e até mesmo promovidos durante o período fascista, era pouco provável que pudessem interpretar a Constituição antifascista com o espírito dos pais fundadores. E ainda, confiando-se a prerrogativa de declarar a inconstitucionalidade de uma lei a uma Corte separada, esperava-se obter da magistratura ordinária a tradicional subordinação às leis. (GUARNIERI, 2011, p. 29).

Não por acaso, outros países europeus adotarão ao final da $2^{\mathrm{a}}$ Guerra Mundial soluções constitucionais semelhantes mediante a criação de cortes de inspiração kelseniana em seus ordenamentos jurídicos, como a Alemanha (1949) e a França (1958). Aquilo de que se tratava era a mudança de um arranjo institucional fundado no princípio da supremacia do parlamento em direção a outro modelo institucional fundado no princípio da supremacia da Constituição. Isso ocorre em um contexto marcado por uma visão pessimista acerca da possibilidade de se atribuir exclusivamente ao Poder Legislativo a competência para decidir sobre a constitucionalidade leis. Tal solução tende cada vez mais a ser vista como não satisfatória, já que como o próprio fascismo demonstrou, um poder legislativo desprovido de controle, mesmo seguindo procedimentos formalmente legais, pode facilmente levar à contorção do regime democrático.

O caráter relativamente tardio da introdução e difusão do controle de constitucionalidade 
na Europa decorreu em parte de uma associação entre a noção de soberania popular e supremacia do parlamento que se afirma a partir da Revolução Francesa de 1789. Daí uma hostilidade com relação a qualquer tipo de controle, especialmente de constitucionalidade, exercido por um órgão extraparlamentar.

\begin{abstract}
O atraso europeu em relação ao sistema norte-americano pode estar ligado à influência que a doutrina revolucionária francesa teve sobre os arranjos políticos de muitos sistemas continentais, alimentando sua tendência de concentrar o poder ao invés de dividi-lo (...). A ênfase que a ideologia jacobina coloca na soberania popular e nas instituições que a expressam leva a afirmar a supremacia das assembleias e, em última instância, da regra da maioria. (...) O que está consolidado no continente é um arranjo piramidal que formalmente afirma o primado do parlamento (...) e o sustenta também ao subordinar o juiz à sua vontade, ou melhor, à vontade da lei. (PEDERZOLI, 2008, p. 21-22, tradução dos autores).
\end{abstract}

A atual Constituição, ao contrário do Estatuto Albertino, é considerada uma Constituição rígida, quer dizer, modificável apenas através de um procedimento relativamente complexo, sendo que algumas de suas disposições não podem ser objeto de revisão constitucional, tal como prescreve o artigo 139, ipsis litteris: “A forma republicana não pode ser objeto de revisão constitucional". Além do mais, a doutrina quase unanimemente entende que nem a natureza democrática da Constituição, expressa nos direitos de liberdade dos cidadãos, possa ser afetada e transformada por revisão constitucional.

A complexidade do procedimento de revisão da Constituição delineado no artigo 138 destina-se a assegurar que o Parlamento se expresse de uma forma ponderada, não sob urgências emocionais ou adquiridas, e que também seja possível a intervenção de uma pluralidade de atores (PASQUINO, 2011, p. 111). Segundo o artigo 138 da Constituição italiana

\footnotetext{
As leis de revisão da Constituição e as outras leis constitucionais são adotadas por cada Câmara com duas deliberações sucessivas com intervalo não inferior a três meses, e são aprovadas pela maioria absoluta dos membros de cada Câmara na segunda votação.

As próprias leis estão sujeitas a um referendo popular quando, no prazo de três meses de sua publicação, um quinto dos membros de uma Câmara ou quinhentos mil eleitores ou cinco Conselhos Regionais o solicitarem. A lei submetida a referendo não é promulgada se não for aprovada pela maioria dos votos válidos.Nenhum referendo é realizado se a lei foi aprovada na segunda votação de cada uma das Câmaras por uma maioria de dois terços de seus membros (ITALIA, COSTITUZIONE, 1948, tradução dos autores).
}

\title{
2. O CONTROLE DE CONSTITUCIONALIDADE
}

Quais são os atores legitimados no ordenamento jurídico italiano a acionar a jurisdição da Corte? Quais são as vias de acesso à Corte? Em que momento é realizado o controle de constitucionalidade? Tais questões encontram resposta tanto no texto da Constituição quanto na legislação infraconstitucional italianas.

Na Itália, o controle jurisdicional de legitimidade constitucional de leis e atos normativos 
é caracterizado como concentrado na Corte Constitucional e de caráter repressivo (posterior), ou preventivo (prévio) conforme o momento em que é realizado, se antes ou após a entrada em vigor das leis ou dos atos normativos sujeitos a controle.

\title{
2.1 O controle em via incidental
}

O controle de constitucionalidade incidenter tantum é sempre repressivo (posterior). É disciplinado pelo art. 1 da Lei Constitucional 9 de fevereiro de 1948, n.1, que determina que será remetida à Corte Constitucional a questão de legitimidade constitucional detectada de ofício ou levantada por uma das partes no curso de um processo judicial, desde que não entendida pelo juiz como manifestamente infundada. Com efeito, dispõe o referido artigo:

\begin{abstract}
Art. $1^{\circ}$ - A questão de legitimidade constitucional de uma lei ou de um ato com força de lei da República, suscitada de ofício ou apresentada por uma das partes no decorrer do processo e não considerada pelo juiz como manifestamente infundada, é remetida à Corte constitucional para a sua decisão. (ITALIA, LEGGE COSTITUZIONALE N.1, 1948, Tradução dos autores).
\end{abstract}

Além disso, o artigo 23 da Lei 11 de março de 1953, n. 87, permite que, além das partes, o Ministério Público apresente à autoridade jurisdicional a questão de legitimidade constitucional por meio de um pedido específico que deve indicar as disposições da Constituição ou da lei constitucional que supostamente foram violadas.

\footnotetext{
Art. 23 - No curso de um julgamento perante uma autoridade jurisdicional uma das partes ou o Ministério Público podem apresentar uma questão de legitimidade constitucional por meio de um pedido específico indicando:

(...)

b) as disposições da Constituição ou das leis constitucionais, que se presume terem sido violadas. (...) (ITALIA, 1953, n.87, tradução dos autores).
}

Note-se que o Ministério Público, do ponto de vista da proposição das questões incidentais, não é assimilado ao juiz, mas às partes. Com isso, a sua iniciativa no processo incidental não é direta, mas deve passar necessariamente pelo controle do juiz perante o qual se desenvolve o processo (ZAGREBELSKY e MARCENÒ, 2012, p. 281).

Uma vez arguida pelas partes a questão de legitimidade constitucional de uma lei ou ato normativo, compete ao juiz, de acordo com o art.1 da Lei Constitucional n.1 de 1948, analisar se a questão suscitada não é manifestamente infundada, para só então remetê-la à Corte Constitucional. Ou seja, o magistrado realiza uma espécie de juízo de admissibilidade da questão de constitucionalidade.

Ao juiz compete, portanto, impedir o prosseguimento da iniciativa da parte nos casos em que a questão seja irrelevante ou manifestamente infundada, ou, no caso contrário, abrir a estrada de acesso à Corte Constitucional (ZAGREBELSKY e MARCENÒ, 2012, p. 295).

$\mathrm{Na}$ caracterização feita do sistema italiano por Pasquale Pasquino: 
No sistema constitucional italiano, o envio para a corte constitucional é quase monopolizado por tribunais comuns. Os juízes enviam casos que têm que decidir a Roma, ao órgão especializado chamado Corte Costituzionale, sempre que tiverem uma "dúvida razoável" [non manifesta infondatezza] sobre a constitucionalidade da lei que eles - os juízes comuns - devem aplicar. Mais exatamente, quando pensam que aplicar a lei produzirá algum tipo de injustiça (não apenas uma contradição entre normas superiores e inferiores, para falar como os teóricos legais Kelsenianos). (PASQUINO, 2001, p. 3, tradução dos autores).

Nas palavras de Patrizia Pederzoli:

O controle em via incidental impõe restrições estritas ao indivíduo, que só pode contestar a lei apenas por meios judiciais, desde que seja parte de um processo (...). As dúvidas de constitucionalidade que podem ser apresentadas aqui devem então ter algum fundamento, não ser, por exemplo, pretestuosas, e empregar apenas disposições legislativas úteis para resolver a disputa. É o juiz comum que avalia estes dois requisitos, a "não manifesta falta de fundamento" e a "relevância". Se persuadido, ele deverá suspender o processo e motivá-los no ato de envio com o qual ele ativa a Corte. De sua decisão discricionária depende, portanto, a oportunidade de os indivíduos obterem um julgamento sobre a lei a ser aplicada à disputa. Mais importante, o juiz pode promover uma questão de legitimidade constitucional de oficio, sem ser solicitado pelas partes explicando sua relevância e fundamento. Se no primeiro caso ele seleciona as questões que chegarão à Corte, exercitando na prática um poder de veto e, em qualquer caso, filtrando os argumentos apresentados em juízo, no segundo se coloca como um ator que promove sua intervenção com plena autonomia e iniciativa própria. Por isso, é uma função de particular importância, que o leva a definir a agenda da justiça constitucional e ser seu "porteiro" (...) pelo menos no âmbito desse procedimento. (PEDERZOLI, 2008, p. 52-53, tradução dos autores).

A relevância da questão de legitimidade constitucional apta a ser remetida à Corte exprime uma conexão objetiva entre a questão e o processo a quo. Essa relação diz respeito ao fato de que a questão deve estar diretamente ligada ao caso concreto, isto é, a resolução do mesmo deve depender do julgamento da legitimidade da questão constitucional que foi detectada pelo juiz ou arguida pela parte.

Observa-se que a decisão que denega a exceção de ilegitimidade constitucional por entendê-la manifestamente irrelevante ou infundada, deve ser devidamente motivada, e a exceção pode ser proposta novamente em cada grau posterior de jurisdição, de acordo com o artigo 24 da Lei Constitucional 11 de março de 1953, n.87:

Art. 24 - $\mathrm{O}$ ato que rejeitar a exceção de ilegitimidade constitucional por manifesta irrelevância ou falta de fundamento deve ser adequadamente motivado. A exceção pode ser proposta novamente no início de cada grau posterior do processo. (ITALIA, LEGGE COSTITUZIONALE 11 marzo 1953, n.87, tradução dos autores).

No procedimento de instauração do juízo de constitucionalidade na via incidental ou de exceção, a questão de constitucionalidade não se coloca por si mesma, mas na verdade como um incidente ou exceção processual no curso de um processo judicial; o procedimento é concreto, porque a lei é considerada no momento e em sua aplicação; é geral, podendo-se considerar todas 
as leis no momento de suas aplicações; e por último, é indisponível, já que o juiz, quando cumpridas as condições, é obrigado a promovê-lo (ZAGREBELSKY; MARCENÒ, 2012, p. 268).

Relativamente à iniciativa incidental de instauração de um juízo de controle de constitucionalidade, observa-se, primeiramente, que a questão de constitucionalidade deve surgir no curso de um processo que tramita perante uma autoridade judiciária (art.1 da Lei Constitucional n.1 de 1948 e art. 23 da Lei n. 87 de 1953), cabendo às partes levantá-la ao juiz ou a este detectá-la de ofício.

Entre as duas iniciativas há uma diferença fundamental: o poder das partes é indireto, e o do juiz é direto. As partes do processo, na verdade, apenas levantam a questão frente ao juiz da causa, e este, verificando que a questão não é manifestamente infundada, a transmite à Corte Constitucional; o juiz, ao contrário, ao ver-se diante de uma questão de legitimidade constitucional, a promove diretamente frente à Corte (ZAGREBELSKY e MARCENÒ, 2012).

É justamente em razão da impossibilidade de as partes recorrerem diretamente à Corte que se costuma dizer que a iniciativa no procedimento incidental é sempre e somente do juiz da causa, de ofício ou provocado pelas partes.

Gustavo Zagrebelsky e Valeria Marcenò (2012, p. 279, 280) afirmam que esta perspectiva é válida apenas quando a instauração do juízo de constitucionalidade é analisada por um ângulo externo à iniciativa do juízo a quo: do ponto de vista da Corte, o ato de impulso do juízo de constitucionalidade é do juiz, e somente deste. Se, no entanto, os eventos do processo forem examinados dall'interno, é evidente que as duas iniciativas (das partes e do juiz) não podem ser confundidas. A dupla legitimação corresponde a uma dúplice ratio:

a) para as partes, a questão se configura como instrumento de defesa de direitos e interesses constitucionalmente protegidos, conforme o direito de ação previsto no artigo 24 da Constituição italiana. Tal direito de ação é direto em relação ao juiz a quo e indireto (através deste) perante a Corte Constitucional. Com a questão de constitucionalidade, as partes buscam a tutela dos próprios iura, contra a lex (considerada) inconstitucional;

b) para o juiz, não estão em discussão suas considerações subjetivas; ele está interessado em defender a sua posição institucional, a posição de intermediariedade entre lei e Constituição. Apresentando de ofício a questão de constitucionalidade o juiz não só se preocupa com uma abstrata coerência do ordenamento jurídico, mas defende uma posição que lhe é garantida, não como executor burocrático da lei, mas de intérprete e garantidor de um mais profundo significado do direito, em um estado regido por uma Constituição rígida.

A separação das legitimações é necessária, conforme argumentam Zagrebelsky e Marcenò (2012, p. 80), porque não seria admissível a defesa judiciária dos direitos individuais confiada paternalisticamente a sujeitos diversos, embora operando em vista de exigências institucionais objetivas: o direito de ação é garantido pelo art. 24 da Constituição como um direito a exercício pessoal e direto. 
Art. 24 - Todos podem agir em juízo para a tutela de seus próprios direitos e interesses legítimos.

A defesa é um direito inviolável em todas as fases e graus do procedimento.

Os meios para agir e defender-se diante de qualquer jurisdição são assegurados aos necessitados, com institutos apropriados.

A lei determina as condições e métodos para a reparação de erros judiciais. (ITALIA, COSTITUZIONE, 1948, tradução dos autores)

Enfim, no controle realizado através da via incidental, o procedimento constitucional é instaurado no momento em que a ordem de remessa (art. 23 da Lei n. 87 de 1953) chega à Corte e, após ser submetida a um controle preliminar de regularidade realizado por seu Presidente, aí se desenvolve integralmente sem qualquer intromissão do juízo a quo. A relação processual originária não se coloca de frente do juízo de constitucionalidade, tratando-se de juízos profundamente diversos em seus objetos, caracteres e sujeitos. Como já mencionado, o procedimento perante a Corte é de direito objetivo, onde se predomina o princípio da oficialidade e se prescinde da necessidade da constituição de uma relação processual entre parte e juiz. Observa-se, todavia, que aberto o incidente de inconstitucionalidade, pode-se realizar um contraditório com o reconhecimento de direitos processuais a sujeitos que, em várias qualidades, intervenham na causa.

\subsection{0 controle em via principal}

Tal procedimento de controle de constitucionalidade, previsto diretamente na Constituição italiana, é promovido em via principal ou de ação, já que a questão de constitucionalidade é posta como um processo ad hoc; é abstrato, já que as leis ou atos impugnados são considerados pelo que prescrevem, independentemente de suas aplicações concretas; é específico, sendo que o controle operante não incide sobre a inconstitucionalidade de leis e atos em geral, mas sobre a incompetência dos entes responsáveis pela edição dos mesmos; e, por fim, é disponível, já que os entes envolvidos podem (é uma faculdade) ou não fazer o uso de seus poderes de recurso à Corte.

\footnotetext{
Muito do que foi dito, no que diz respeito à eficácia ou objeto do juízo, também se aplica ao controle abstrato ou em via principal, assim definido porque pedido por determinadas autoridades, sem ser mediada pelo juiz comum e, portanto, referido a regras ainda não contestadas em um processo. (PEDERZOLI, 2008, p. 61, tradução dos autores).
}

No sistema de controle de constitucionalidade italiano estão previstas três hipóteses de controle de constitucionalidade que são exercitados em via principal, ou de ação.

A primeira é aquela inserida no ordenamento jurídico italiano através da Lei Constitucional 22 de novembro de 1999, n.1, que alterou o artigo 123 da Constituição italiana e possibilitou ao Governo da República a arguição, perante a Corte Constitucional, de ilegitimidade constitucional de estatuto regional (que determina a forma de governo e os princípios fundamentais de organização e funcionamento de cada região) dentro do prazo de trinta dias após 
sua publicação. O caráter preventivo foi entendido como tal pela própria Corte Constitucional ao prolatar a sentença n. 304 de 2002. Quanto ao exposto, sustenta o artigo 123 da Constituição italiana:

Art. 123 - Cada Região tem um estatuto que, em harmonia com a Constituição, sua forma de governo e seus princípios fundamentais de organização e funcionamento.

O estatuto regula o exercício do direito de iniciativa e o referendo sobre as leis e disposições administrativas da Região e a publicação de leis e regulamentos regionais.

O estatuto é aprovado e modificado pelo Conselho Regional com lei aprovada pela maioria absoluta de seus membros, com duas deliberações sucessivas adotadas em intervalos não inferiores a dois meses.

Para esta lei, não é necessário apor o visto pelo Comissário do Governo.

O Governo da República pode promover a questão de legitimidade constitucional sobre os estatutos regionais perante a Corte Constitucional no prazo de trinta dias após a sua publicação.

O estatuto é submetido a um referendo popular quando, no prazo de três meses de sua publicação, o requeiram um cinquentésimo dos eleitores da Região ou um quinto dos membros do Conselho Regional o solicitarem. A lei submetida a referendo não é promulgada se não for aprovada pela maioria dos votos válidos. (...) (ITALIA, 1948, tradução dos autores).

Em meio à controvérsia acerca do caráter repressivo ou preventivo do controle de constitucionalidade sancionado pelo art. 123 da Constituição italiana, afirmam Gustavo Zagrebelsky e Valeria Marcenò (2012, p.334-335):

Desde a entrada em vigor da nova disposição constitucional, colocou-se a questão sobre o caráter preventivo ou subseqüente do controle sobre os estatutos regionais. Isso porque o art. 123 da Constituição faz decorrer o prazo para a apresentação do recurso do governo "da publicação" dos estatutos. Qual "publicação"? A questão não era trivial, envolvendo a relação entre o procedimento agravado para a formação da lei estatutária e o procedimento de controle de sua legitimidade constitucional. Ambos os procedimentos referemse a termos que ocorrem "desde a publicação" do ato (dentro de três meses da publicação, um referendo popular pode ser solicitado, e dentro de trinta dias da publicação, um recurso do governo pode ser apresentado). No primeiro caso, no entanto, até mesmo por analogia com o processo previsto para a formação de leis constitucionais (Art. 138 Const.), trata-se certamente de uma publicação "noticial", que é feita antes da consumação do procedimento, para permitir a iniciativa do referendo; no segundo caso, no entanto, nada é explicitamente dito. A consequência é que, referindo-se à publicação-notícia, o controle da constitucionalidade na lei estatutária antecede a realização do referendo (e, portanto, seu desfecho não corre o risco de colidir com uma possível vontade contrária expressa pelos cidadãos); Referindo-se ao vigor da publicação, o controle da constitucionalidade torna-se sucessivo ao referendo, com a possibilidade de contradição entre os resultados de um e do outro. (...) A questão interpretativa (...) foi resolvida pela Corte (...). Essa afirmou que "o prazo para promover o controle da legitimidade constitucional começa a partir da publicidade "noticial" da deliberação estatutária e não daquela sucessiva à promulgação, que é condição para entrada em vigor "(...) O controle é, portanto, preventivo: antecede o eventual referendo (tradução dos autores).

A segunda hipótese de controle de constitucionalidade em via principal pela Corte Constitucional é de tipo repressivo (posterior) e está prevista no artigo 127 da Constituição 
italiana, que trata da possibilidade de que o Governo, quando entender que uma lei regional excedeu a competência da Região, possa promover uma questão de legitimidade constitucional perante a Corte Constitucional dentro do prazo de 60 dias após sua publicação; e que as regiões também podem, quando entenderem que uma lei ou um ato normativo do Estado ou de outra Região interfere em sua esfera de competência, promover uma questão de legitimidade constitucional perante a Corte Constitucional no mesmo prazo de 60 dias após a publicação da lei ou do ato:

Art. 127 - O Governo, quando considerar que uma lei regional excede a competência da Região, pode promover a questão da legitimidade constitucional perante a Corte Constitucional no prazo de sessenta dias de sua publicação.

A Região, quando considera que uma lei ou ato que tenha força de lei do Estado ou de outra Região ofende sua esfera de competência, pode promover a questão da legitimidade constitucional perante a Corte Constitucional dentro de sessenta dias da publicação da lei ou do ato com força de lei. (ITALIA, 1948, tradução dos autores).

A propósito dos recursos constitucionais do Estado contra as Regiões e das Regiões contra o Estado, afirmam Gustavo Zagrebelsky e Valeria Marcenò (2012, p. 321):

O controle que se instaura em seguida ao recurso é, como é claramente deduzido a partir da formulação da disposição constitucional, um controle posterior, que é realizado em leis, estatais ou regionais, depois que tenham entrado em vigor.

Por sua vez, o juízo de constitucionalidade exercido em via principal considera-se instaurado no momento em que o recurso é depositado na secretaria da Corte Constitucional e supera o controle preliminar de regularidade, nos termos do art. 23 das Normas Integrativas para os Julgamentos perante a Corte Constitucional, de 16 de março de 1956.

A Corte, ao decidir o mérito da questão de legitimidade constitucional, pode adotar duas posturas: a rejeição, (rigetto) ou o acolhimento, através da denominada sentenza de accoglimento. No primeiro caso, nada muda e a lei continua vigente, mas no segundo, a lei é eliminada. A sentença que declara a inconstitucionalidade da lei pode ser considerada como uma decisão que constata e remove um estado de dúvida, sancionando definitiva e oficialmente um vício préexistente.

O efeito da decisão que declara a ilegitimidade constitucional de uma lei ou um ato normativo está estabelecido no artigo 136 da Constituição da República italiana, segundo o qual a declaração de inconstitucionalidade causa a perda de eficácia da lei ou do ato contrários à Constituição.

Art. 136. Quando a Corte declara a ilegitimidade constitucional de uma lei ou ato com força de lei, a lei deixa de ter efeito a partir do dia seguinte à publicação da decisão.

A decisão da Corte é publicada e comunicada às Câmaras e Conselhos 
regionais interessados, para que, quando julgarem necessário, procedam de acordo com as formas constitucionais. (ITALIA 1948, tradução dos autores).

Não se espera que a Corte disponha acerca das consequências da declaração de inconstitucionalidade: a Corte se ocupa da declaração de ilegitimidade de um dispositivo, mas não pode gerir os efeitos resultantes desta declaração (ZAGREBELSKY; MARCENÒ, 2012, p. 346).

A lei ou o ato declarado inconstitucional perde sua eficácia a partir do dia seguinte ao da publicação da decisão que declarou sua inconstitucionalidade, e nenhum evento sucessivo à publicação é idôneo a conferir novamente eficácia à lei declarada inconstitucional (art. 136 da Constituição italiana), o que sugere um efeito geral pro futuro, ou seja, ex nunc, já que a declaração de inconstitucionalidade influi nas situações e relações jurídicas posteriores à publicação da decisão, mas não sobre as que surgiram anteriormente. Esta foi certamente e inequivocamente a intenção do constituinte (ZAGREBELSKY e MARCENÒ, 2012, p. 346).

Ocorre que, analisando o efeito previsto no artigo 136 da Constituição italiana sob o aspecto do juízo a quo, percebe-se que no controle de constitucionalidade exercido em via incidental, se a decisão de inconstitucionalidade só pudesse surtir efeitos após sua publicação, certamente ninguém, nem o juiz e nem as partes, teria interesse em promover a questão de constitucionalidade, já que independentemente da decisão proferida pela Corte Constitucional, o juízo a quo teria de aplicar ao caso a lei vigente ao momento de seu julgamento.

Esta incongruência foi levada em conta pelo artigo 30 da Lei n. 87 de 1953, que estabeleceu que, a partir do dia seguinte à publicação, a lei declarada inconstitucional não pode ter aplicação.

Como asseveram Gustavo Zagrebelsky e Valeria Marcenò (2012, p. 350, 351), as duas fórmulas (cessação de eficácia e não-aplicação da lei declarada inconstitucional) não são equivalentes; de fato, são expressões de dois entendimentos diversos: com o artigo 136 o Constituinte objetivava limitar o efeito da declaração de inconstitucionalidade às situações posteriores à decisão da Corte; e com o artigo 30 o legislador procurou evitar, no que foi possível, a aplicação da lei reconhecida como inconstitucional. Apesar de não serem equivalentes, as duas normas não são contraditórias. Há uma relação de integração entre elas. O art. 136 - com a expressão "cessação de eficácia" - disciplina os efeitos futuros e abstratos da decisão de inconstitucionalidade sobre a vigência da lei em geral; o artigo 30 - com a expressão "desaplicação" - disciplina os efeitos sobre as relações passadas e concretas, nos julgamentos particulares que lhe dizem respeito.

O efeito da decisão da Corte Constitucional é então, para o futuro, um efeito substancial análogo à ab-rogação; e para o passado, um efeito processual que se reflete naturalmente sobre o plano das relações substanciais em curso. Este reflexo abre a estrada para a considerada retroatividade dos efeitos da declaração de inconstitucionalidade no controle de 
constitucionalidade italiano.

Observa-se, no entanto, que apesar de os efeitos retroativos da decisão de inconstitucionalidade operarem, por regra, sobre as relações processuais em curso, isto é, pendentes, o artigo 30 da Lei n. 87 de 1953 abre uma exceção que permite que estes efeitos retroativos atinjam relações jurídicas exauridas, que é a retroatividade em matéria penal. Com isso, as sentenças condenatórias, mesmo que transitadas em julgado, cessam sua execução e produção de efeitos quando a lei que ensejou o decreto condenatório foi declarada inconstitucional.

Eis o que dispõe o artigo 30 da Lei n. 87 de 1953:

Art. 30. A sentença que declara a ilegitimidade constitucional de uma lei ou de um ato com força de lei do Estado ou de uma Região, no prazo de dois dias de seu depósito na Secretaria, é transmitida, de ofício, ao Ministro de Justiça ou ao Presidente do Conselho regional de modo a que se proceda imediatamente e, no máximo em dez dias, a publicação do dispositivo na mesma forma estabelecida para a publicação do ato declarado inconstitucional.

A sentença, no prazo de dois dias a contar da data do depósito, é também comunicada às Câmaras e Conselhos regionais interessados, para que, quando julgarem necessário, adotem as medidas de sua competência.

As regras declaradas inconstitucionais não podem ser aplicadas a partir do dia seguinte à publicação da decisão.

Quando uma sentença de condenação irrevogável tenha sido proferida nos termos da disposição declarada inconstitucional, cessam sua execução e todos os seus efeitos penais. (ITALIA 1953, tradução dos autores).

Por último, uma terceira modalidade distinta de controle pela via principal ocorre com relação ao controle de constitucionalidade exercido, preventivamente, em se tratando da hipótese prevista no artigo 75 da Constituição italiana e disciplinada pela Lei Constitucional 11 de março de 1953, n.1; e pela Lei 25 de maio de 1970, n. 352, relativamente à figura do referendum revogativo (referendum abrogativo).

Segundo os dispositivos legais, far-se-á um referendo popular para deliberar acerca da ab-rogação total ou parcial de uma lei ou de um ato normativo, quando solicitado por quinhentos mil eleitores ou cinco Conselhos regionais, sendo que compete à Corte Constitucional (após comunicação proveniente do órgão competente da Corte di cassazione sobre a legitimidade do pedido de referendo, isto é, que este cumpre os requisitos legais e procedimentais elencados na Lei 25 de maio de 1970, n. 352) decidir se o pedido de referendum revogativo é admissível perante o segundo comando do art. 75 da Constituição, que veda este tipo de referendo para leis tributárias e de balanço, de anistia e de indulto, e de autorização a ratificar tratados internacionais.

Artigo 75 - O plebiscito popular é realizado para deliberar sobre a revogação, no todo ou em parte, de uma lei ou de um ato que tenha força de lei, quando quinhentos mil eleitores ou cinco Conselhos Regionais o solicitarem.

Não é admitido o referendo sobre leis tributárias e orçamentárias, anistia e indulto, e de autorização para ratificar tratados internacionais.Têm direito de participar do referendo todos os cidadãos chamados a eleger a Câmara dos Deputados. (ITALIA, 1948, tradução dos autores). 
Por sua vez, a Lei Constitucional $n^{\circ} 1$ de 11 de março de 1953 dispõe que

Art. $2^{\circ}$ - Compete à Corte Constitucional julgar se os pedidos de plebiscito submetidos nos termos do art. 75 da Constituição são admissíveis nos termos do segundo parágrafo do mesmo artigo. As modalidades deste julgamento serão estabelecidas pela lei que regerá a realização do referendo popular. (ITALIA 1953, tradução dos autores).

Percebe-se, portanto, que o peculiar controle de legitimidade constitucional de referendum revogativo é realizado em via principal e de forma preventiva já que nessa hipótese cabe à Corte Constitucional analisar a admissibilidade do instrumento de soberania popular, que deve estar em conformidade com o artigo 75 da Constituição italiana.

\section{ITÁLIA: UMA CORTE CONSTITUCIONAL DE TIPO KELSENIANO?}

Quando se examina em perspectiva comparada os diferentes sistemas democráticos contemporâneos, uma das variações institucionais mais importantes que se percebe diz respeito à distinção entre, de um lado aqueles sistemas fundados no princípio da soberania do parlamento; e de outro lado aqueles sistemas baseados no princípio da soberania da Constituição. Nos primeiros, o parlamento é soberano em suas decisões, enquanto que nos últimos soberana é a Constituição (SWEET, 2008; MENDES; BRANCO, 2012).

O que se observa é a existência de diferentes modelos constitucionais, sendo que os sistemas fundados no princípio da soberania da Constituição apresentam restrições substanciais ao exercício da autoridade pública - na forma de direitos constitucionais - e estabelecem um meio judicial independente de fazer cumprir direitos, mesmo contra o legislativo. A soberania legislativa é expressamente rejeitada.

Nos sistemas fundados na supremacia da Constituição, diante de uma antinomia de normas jurídicas que oponha a Constituição a outra norma qualquer, deve-se sempre solucionar o conflito em favor da prevalência de norma constitucional hierarquicamente superior. Nisso consiste o chamado controle de constitucionalidade. Resta saber qual instituição, e em que condições, será investida de tal prerrogativa.

Em resposta a essa indagação, é recorrente e amplamente conhecida a contraposição bipolar sistema americano x sistema europeu-kelseniano de controle de constitucionalidade. Nos termos da contraposição, o sistema americano é caracterizado como sendo difuso, incidental, com efeitos inter-partes e declarativo (ex tunc). Já o sistema europeu-kelseniano é concentrado, em via principal, com efeitos erga omnes e constitutivo (ex nunc).

Não obstante seu caráter didático, enquanto facilitador do mapeamento da diversidade institucional que caracteriza o fenômeno do controle de constitucionalidade nos diversos sistemas políticos em que se faz presente, a dicotomia sistema americano x sistema europeu-kelseniano vem sendo questionada á luz da conformação evolutiva dos diferentes órgãos responsáveis pela 
jurisdição constitucional naqueles sistemas fundados no princípio da supremacia da Constituição.

Com efeito, na Europa observa-se uma tendência convergente entre os órgãos de controle de constitucionalidade de diferentes países no sentido da conjugação de elementos que eram parte constitutiva da concepção original de um ou de outro daqueles dois sistemas (americano e europeu-kelseniano) de controle de constitucionalidade. Na síntese de Segado

\begin{abstract}
La enorme expansión de la justicia constitucional ha propiciado uma mixtura e hibridación de modelos, que se ha unido al proceso preexistente de progresiva convergencia entre los elementos, supuestamente contrapuestos antaño, de los dos tradicionales sistemas de control de la constitucionalidad de los actos del poder.

La resultante de todo ello es la pérdida de gran parte de su utilidad analítica de la tan generalmente asumida bipolaridad "modelo americano versus modelo europeo-kelseniano". Como dice Rubio Llorente, hablar hoy de un sistema europeo carece de sentido porque hay más diferencias entre lós sistemas de justicia constitucional existentes en Europa que entre algunos de ellos y el norteamericano. (SEGADO, 2003, p. 58).
\end{abstract}

Também no Brasil observa-se algo semelhante ao longo da evolução do nosso controle de constitucionalidade. A Constituição de 1891 consagra a adoção do modelo difuso e incidental importado dos Estados Unidos que se manterá até os dias de hoje, ao passo que o controle concentrado por via principal (modelo europeu kelseniano) sé será incorporado ao nosso sistema de controle de constitucionalidade com Emenda Constitucional n. 16/65 à Constituição de 1946.

Embora tenha mantido tal sistema híbrido, a Constituição de 1988 trouxe importantes inovações em nosso sistema de controle de constitucionalidade que permitem identificar uma nítida tendência evolutiva no sentido do alargamento da jurisdição constitucional abstrata e concentrada exercitada pelo Supremo Tribunal Federal. De fato, constata-se que algumas das inovações contidas na Constituição de 1988 aumentaram a centralidade e promoveram especialmente a ampliação das prerrogativas do Supremo Tribunal Federal, tais como a ampliação do rol dos legitimados para a propositura de ação direta de inconstitucionalidade (art. 103); a introdução de mecanismos de controle da inconstitucionalidade por omissão (art. 103, § $2^{\circ}$ e art. $5^{\circ}$, LXXI); a previsão de um mecanismo de arguição de descumprimento de preceito fundamental (art. $102, \S 1^{\circ}$ ); e conferiu-se ao Supremo Tribunal Federal a possibilidade do produzir súmulas vinculantes (art.103-A) que fortalecem a autoridade das decisões do Tribunal frente às instâncias inferiores do Poder Judiciário (BARROSO, 2012; MENDES; BRANCO, 2014). Nesse sentido

A Constituição de 1988 conferiu ênfase, portanto, não mais ao sistema difuso ou incidente, mas ao modelo concentrado, uma vez que, praticamente, todas as controvérsias constitucionais relevantes passaram a ser submetidas ao Supremo Tribunal Federal, mediante processo de controle abstrato de normas. A ampla legitimação, a presteza e a celeridade desse modelo processual, dotado inclusive da possibilidade de suspender imediatamente a eficácia do ato normativo questionado, mediante pedido de cautelar, constituem elemento explicativo de tal tendência. (MENDES E BRANCO, 2014, p. 995). 
I - No caso italiano, uma primeira característica institucional que afasta sua jurisdição constitucional do modelo proposto por Kelsen sem, contudo, equipará-la ao modelo americano diz respeito à mitigação do monopólio do exercício do controle concentrado de constitucionalidade pela Corte Constitucional. De fato, depois da Áustria (1929), Itália (1948) e Alemanha (1949) no pós-segunda guerra e Espanha (1978) evoluíram no sentido da atenuação da contraposição entre sistema americano e sistema europeu-kelseniano de controle de constitucionalidade (SEGADO, 2003; FAVOREAU, 2004).

Tal fenômeno é fruto de uma combinação entre a técnica de controle incidental (sistema americano) com a técnica de controle concentrado (sistema europeu-kelseniano) mediante o instituto da pregiudizialità. Segundo Cappelletti:

É evidente que, deste modo, nos sistemas italiano e alemão se veio a por em prática, sob o aspecto "modal" que estamos aqui examinando, uma notável aproximação ao sistema "americano" da judicial review, porque, embora na Itália e n Alemanha não aconteça que todos os juízes sejam (como nos Estados Unidos) competentes para efetuar o controle de constitucionalidade, todos, porém, são, pelo menos, legitimados a requerer tal controle à Corte Constitucional, por ocasião dos casos concretos que eles estejam obrigados a julgar. (CAPPELLETTI, 1992, p. 110-111).

No caso italiano isso ocorre, como visto anteriormente, em virtude do controle de constitucionalidade incidenter tantum. Na hipótese, a questão de legitimidade constitucional detectada de ofício ou levantada por uma das partes ou pelo Ministério Público no curso de um processo judicial, desde que não entendida pelo juiz como manifestamente infundada, é remetida à Corte Constitucional para decisão. Segundo Groppi:

Por lo tanto, también en los sistemas de justicia constitucional concentrada
como los europeos, los jueces comunes están desvinculados de la obligación
de aplicar siempre y en todo caso la ley cuando la consideren inconstitucional:
cierto, no pueden desaplicarla, como sucede en los sistemas de control difuso,
pero se establece una tercera vía, intermedia entre la obligación de aplicarla y
la posibilidad de no aplicarla, que permite al juez suspender el proceso y
remitir la cuestión de inconstitucionalidad, en vía incidental, al juez especial.
(GROPPI, 2005).

É importante notar que os sistemas europeus não acolhem o caráter difuso do exercício da jurisdição constitucional característica da experiência norte-americana. Em nome do "privilégio do legislador", o juiz comum não pode deixar de aplicar a lei, que é um produto do Parlamento sujeito a um juiz especial.

Más allá de las clasificaciones, siempre opinables, debe subrayarse que el modelo europeo de justicia constitucional, a pesar de la presencia en él de elementos propios del modelo estadounidense a causa de la introducción del control concreto, continúa negando a los jueces comunes la posibilidad de desaplicar las leyes contrarias a la Constitución: en otros términos, continúa existiendo un sistema "de privilegio del legislador". Lo que se introduce con la experiencia alemana e italiana, mediante el control concreto, es la posibilidad, para los jueces comunes, de "rebelarse" contra las leyes 
inconstitucionales, dirigiéndose al juez especial del legislador. Esta posibilidad hoy está presente, con la única excepción de Francia, en todos los sistemas europeos y puede por tanto ser considerada justamente una característica del modelo europeo de justicia constitucional. (GROPPI, 2005).

Nesse caso, a questão de legitimidade constitucional implica sempre em um duplo juízo de constitucionalidade: um provisório e negativo formulado pelo juízo que encaminha a questão à Corte Constitucional, e outro definitivo, formulado pela Corte Constitucional, que pode coincidir ou não com aquele primeiro juízo. Assim, tem-se a introdução de um componente difuso no controle de constitucionalidade italiano estranho à formulação original kelseniana.

Nos termos postos por Gustavo Zagrebelsky e Valeria Marcenò:

[...] a escolha a favor da instauração do juízo incidental sobre as leis colocou em crise, em alguns aspectos importantes, a "pureza", por assim dizer, dos caracteres do sistema concentrado, podendo o juízo ser promovido por iniciativas "difusas" provenientes de juízos pendentes diante de juízes comuns. Esse enxerto fez com que algumas características do modelo concentrado abstratamente considerado não fossem mais sustentáveis e inseriu nele alguns aspectos do controle difuso (...)

Esses aspectos do sistema adotado na Itália certamente encurtaram as distâncias entre o sistema "concentrado" conforme originalmente concebido e o sistema difuso, mas não as eliminaram completamente. (ZAGREBELSKY e MARCENÒ, 2012, p. 264, tradução dos autores).

II - Como consequência da mitigação do controle concentrado de constitucionalidade pela Corte Constitucional, um segundo aspecto do controle de constitucionalidade italiano que o coloca a meio caminho entre o modelo americano e a formulação kelseniana original relacionase com o caráter incidental ou principal do controle de constitucionalidade por parte da Corte Constitucional.

Nesse caso, o instituto da pregiudizialità no sistema de controle constitucional italiano introduz um elemento incidental que contraria as formulações de Kelsen relativas às diferenças entre o sistema americano e o novo modelo de cuja formulação ele, Kelsen, se tornaria o principal artífice.

(...) a instauração do juízo constitucional e, portanto, a implementação de um mecanismo objetivo de garantia, com sentido geral (o controle da legitimidade constitucional da lei enquanto tal), estão subordinados a uma condição particular, que coincide com a utilidade da questão para a resolução de um litígio específico (a garantia de posições jurídicas subjetivas, discutidas em juízo) Nisto se manifesta a matriz concreta da questão (ou seja, sua origem em uma controvérsia singular) e também seu, por assim dizer, propósito específico (ou seja, seu destinação à resolução daquela controvérsia) (...) (ZAGREBELSKY; MARCENÒ, 2012, p. 283-284, tradução dos autores).

Como mencionado anteriormente, no âmbito de um caso concreto o juiz a quo controla a possibilidade de acesso à Corte Constitucional na medida em que cabe a ele a decisão acerca da formulação e envio da questão de constitucionalidade à Corte Constitucional. Com isso, tem-se algo que pode ser qualificado como um processo de concretização do controle de 
constitucionalidade na medida em que a Corte Constitucional é chamada a decidir questões prejudiciais suscitadas no âmbito de casos concretos, o que faz com que tais questões prejudiciais, na forma como são formuladas pelos juízes ordinários, repercutam nas decisões do juízo da Corte (GROPPI, 2010).

Na avaliação de Pizzorusso:

\begin{abstract}
Se se olha para a evolução que o controle constitucional recebeu na Itália desde a sua introdução até hoje, parece indiscutível que a taxa de "concretude" que ele assumiu concretamente resultou globalmente maior do que o que se poderia esperar com base o trabalho preparatório da Constituição e das leis que implementaram a justiça constitucional. E isso, não apenas pela clara prevalência que o juízo incidental na prática assumiu em relação ao juízo principal (que é limitado às controvérsias Estado-Regiões), mas também pela conformação que a Corte deu à sentença incidental (e, surpreendentemente, até mesmo para os julgamentos sobre conflitos de atribuições). Na verdade, ainda que a Corte constitucional tenha por vezes oscilado entre uma concepção rigorosa da "relevância" da questão no que diz respeito ao juízo a quo (em qualquer caso claramente prevalecente, tanto na jurisprudência como na doutrina) e uma concepção mais aberta, a sua configuração como condição de admissibilidade da questão proposta à Corte fez - em minha opinião, corretamente - do juízo incidental um juízo concentrado, mas concreto. (PIZZORUSSO, 2006, p. 8, tradução dos autores).
\end{abstract}

III - Também a natureza dos efeitos das decisões da Corte Constitucional italiana remete a um afastamento relativo da experiência italiana do modelo de justiça constitucional kelseniano. No ordenamento jurídico italiano, assim como ocorre em muitos outros países como Alemanha, Espanha e Portugal, ao invés de uma adesão absoluta à teoria da anulabilidade de caráter constitutivo e com efeitos ex nunc da norma considerada inconstitucional (modelo kelseniano), admite-se a nulidade de caráter declaratório e com efeitos ex tunc da norma inconstitucional (modelo americano).

La introducción del juicio concreto en sistemas concentrados determina relevantes efectos también sobre las sentencias de inconstitucionalidad, que adquieren carácter anulativo, manteniendo eficacia erga omnes, pero retroactiva. Elementos del sistema difuso, por tanto (el carácter concreto del proceso, los efectos retroactivos de las sentencias), penetran en los sistemas concentrados, obligando a la doctrina a hablar de una superación de la distinción entre sistemas con control difuso/sistemas con control concentrado para clasificar los sistemas en sistemas concretos/abstractos de justicia constitucional. (GROPPI, 2005).

Conforme mencionado, as sentenças de acolhimento, que são aquelas com as quais a Corte Constitucional declara a inconstitucionalidade da norma impugnada, produzem efeitos $e x$ nunc nos termos do art. 136 da Constituição italiana. Tal entendimento, contudo, implicaria em negar que as sentenças da Corte Constitucional produzissem qualquer efeito com relação ao incidente de constitucionalidade suscitado no juízo ordinário responsável pelo envio da questão prejudicial à Corte Constitucional. Se assim fosse, as sentenças da Corte Constitucional não alcançariam as relações e situações jurídicas ainda pendentes que deveriam continuar sendo 
disciplinadas pela norma declarada constitucionalmente ilegítima:

Daí que a Corte tenha decidido, por interpretação sistemática mediante a combinação do referido art. 136 com o art.1 da Lei Constitucional n.1/48, que a ineficácia da lei declarada ilegítima retroage ao momento da remessa da questão de legitimidade à Corte Constitucional. De maneira que a lei impugnada não poderá ser aplicada nos processos em curso já que ao declarar a inconstitucionalidade da norma a Corte Constitucional promove uma interferência processual no âmbito dos processos em curso que desautoriza sua utilização pelo juiz a quo.

A não aplicação da lei declarada inconstitucional nos juízos comuns, relativamente a situações anteriores à decisão da Corte, permite configurar uma forma de retroatividade dos efeitos das decisões de inconstitucionalidade: retroatividade que é o reflexo indireto de situações processuais nas quais os juízes estão proibidos de aplicar leis inconstitucionais em relação a situações substanciais preexistentes. Nesta proibição consiste, portanto, a "retroatividade": não na emanação de uma nova regra referente a relações anteriores, mas, por assim dizer, na "interferência processual" decorrente de novas normas utilizáveis pelos juízes para definir julgamentos antigos. Em suma, não existe qualquer qualificação legislativa, no momento, de situações e relações anteriores regidas por outra norma substantiva. As consequências "retroativas" são apenas indiretas. Falando de retroatividade, é necessário esclarecer que se trata, portanto, de um caso particular, em que não há sucessão de normas: há a consequência no processo da certificação da nulidade da norma com base na qual, caso contrário (em ausência da declaração relativa), teria sido definido. (ZAGREBELSKY; MARCENÒ, 2012, p. 351, tradução dos autores).

Em regra, a retroatividade das sentenças da Corte Constitucional alcança aquelas situações e relações anteriores à pronúncia da Corte ainda não exauridas, ainda não reguladas de forma definitiva. De maneira que permanecem fora do alcance da norma impugnada a coisa julgada, os atos administrativos definitivos e as situações afetadas pelo decurso do tempo (prescrição, decadência e preclusão).

Em geral, são limites à retroatividade todas as vedações que - com o objetivo de consolidar as situações jurídicas e assim garantir a sua segurança - o ordenamento dispõe acerca da contestação de determinadas situações jurídicas. (ZAGREBELSKY; MARCENÒ, 2012, p. 352, tradução dos autores).

Importante notar que os limites da retroatividade das sentenças da Corte Constitucional são dados não pelo texto constitucional, mas sim pelas normas legislativas que configuram o exaurimento de situações jurídicas. Não se trata de uma questão de direito processual constitucional, mas sim dos limites previstos na legislação acerca da possibilidade de revisão de situações e relações jurídicas.

Já em matéria penal, extinguem-se a execução e os efeitos da sentença condenatória irrecorrível decorrente da aplicação da norma impugnada.

Quando pronunciada sentença de condenação irrevogável com base na aplicação de norma declarada inconstitucional, cessam sua execução e todos os efeitos penais. (ITALIA 1953, tradução dos autores). 


\section{CONSIDERAÇÕES FINAIS}

Introduzida no ordenamento institucional da República italiana pela Constituição de 1948, a Corte Constitucional italiana tem sua normação constitucional definida nos arts. 134 a 137 em Título próprio (Título VI - Garantias Constitucionais) diverso daquele dedicado ao Poder Judiciário (Título V - A Magistratura). Assim, é nítido o enquadramento constitucional da Corte constitucional como instituição não pertencente ao Poder Judiciário italiano cujo órgão de cúpula é a Corte Suprema de cassação (ITALIA, 1941, art. 65). Isso é o que faz com que muitos identifiquem a Corte constitucional como uma corte de tipo kelseniano, uma vez que uma instituição externa ao Poder Judiciário concentra o exercício do controle de constitucionalidade na Itália.

Contudo, as observações anteriores conduzem à avaliação de que o caso italiano situa-se em algum ponto entre os modelos americano e kelseniano de controle de constitucionalidade. Como visto, o sistema de controle de constitucionalidade existente caracteriza-se por uma modalidade de combinação de controle concentrado e controle difuso; de controle concreto e abstrato; e por sentenças constitucionais que em geral têm efeitos ex nunc, mas que também produzem efeitos retroativos (ex tunc) na esfera penal e naquelas situações juridicamente pendentes. Tais características, se não fazem da Corte Constitucional um exemplar do modelo de controle de constitucionalidade americano, tampouco permitem uma identificação absoluta com as formulações kelsenianas para a justiça constitucional.

\section{REFERÊNCIAS}

BARROSO, Luis Roberto. O Controle de Constitucionalidade no Direito Brasileiro. $6^{\mathrm{a}}$ ed. São Paulo: Ed. Saraiva, 2012.

CAPPELLETTI, Mauro. O Controle Judicial de Constitucionalidade das Leis no Direito Comparado. Porto Alegre: Sergio Antonio Fabris Editor, 1992.

FAVOREAU, Louis. As Cortes Constitucionais. São Paulo: Lady Editora, 2004.

GROPPI, Tania. The Italian Constitutional Court: towards a 'multilevel system' of constitutional review? Indian Journal of Constitutional Law, 1. 2010. Disponível em: http://www.astrid-online.it/static/upload/protected/Ital/Italy-constitutional-CourtJCL_T_Groppi.pdf. Acesso em: 15 dez. 2020.

GROPPI, Tania. ¿Existe um Modelo Europeu de Justicia Constitucional? Revista de Derecho Politico, n.62 2005. Disponível em:

http://revistas.uned.es/index.php/derechopolitico/article/view/8952/8545 Acesso em: 15 dez. 2020.

ITALIA. Regio decreto del 30 gennaio 1941, n. 12. Disponível em: 48c38166-4aff-47f1be15-4abe982b3c12 (consiglionazionaleforense.it). Acesso em: 15 dez. 2020.

ITALIA. Costituzione Della Repubblica Italiana. 1948. Disponível em: La Costituzione della Repubblica Italiana - con note (cortecostituzionale.it). Acesso em: 15 dez. 2020.

ITALIA. Legge Costituzionale. 9 febbraio 1948, n.1. Norme sui giudizi di legittimità costituzionale e sulle garanzie d'indipendenza della Corte costituzionale. Disponível em: CC_SS_fonti_lc_09021948_n_1_rev.pdf (cortecostituzionale.it). Acesso em: 15 dez. 2020. 
ITALIA. Legge 11 marzo 1953, n. 87. Norme sulla costituzione e sul funzionamento della Corte costituzionale. Disponível em: LEGGE_11_marzo_1953.pdf (cortecostituzionale.it). Acesso em: 15 dez. 2020.

KELSEN, Hans. A Garantia Jurisdicional da Constituição (A Justiça Constitucional). Revista Direito Público, v.1, n.1, 2003. Disponível em: https://www.portaldeperiodicos.idp.edu.br/direitopublico/article/view/1401/869. Acesso em: 15 dez. 2020.

MENDES, Gilmar e BRANCO, Paulo Gustavo Gonet. Curso de Direito Constitucional. 9a ed. São Paulo: Ed. Saraiva, 2014.

PIZZORUSSO, Alessandro. La giustizia costituzionale fra modello "difuso" e modello "concreto". Fundamentos: Cuadernos monográficos de teoria del estado, derecho público e historia constitucional, n. 4, 2006. Disponível em: https://dialnet.unirioja.es/servlet/articulo?codigo=2060304. Acesso em: 15 dez. 2020.

SEGADO, Francisco Fernández. La Obsolescencia de la Bipolaridad Tradicional (Modelo Americano - Modelo Europeo-Kelseniano) de los Sistemas de Justicia Constitucionnal. Revista Direito Público, n.2, 2003. Disponível em:https://www.portaldeperiodicos.idp.edu.br/direitopublico/article/view/1394/862. Acesso em: 10 set. 2020.

SWEET, Alec Stone. Constitutions and judicial Power. In: CARAMANI, D. (ed.). Comparative Politics, Oxford: Oxford University Press, 2008.

WEBER, Albrecht. La Jurisdicción Constitucional en Europa Occidental: una comparación. Revista Española de Derecho Constitucional, v. 6, n. 17, 1986. Disponível em: https://dialnet.unirioja.es/ejemplar/8050. Acesso em: 10 set. 2020.

ZAGREBELSKY, Gustavo; MARCENÒ, Valeria. Giustizia Costituzionale. Bologna: Il Mulino, 2012.

Artigo recebido em: 2021-03-26

Artigo reapresentado em: 2021-04-12

Artigo aceito em: 2021-04-12 